\title{
Speech Acts Strategies of “Refusing” by Indonesian in France Language
}

\author{
Jubliana Sitompul $^{1}$ \\ ${ }^{1}$ Faculty of Languages and Arts Universitas Negeri Medan, Indonesia \\ Correspondence: Jubliana Sitompul, Faculty of Languages and Arts, Universitas Negeri Medan, Jl. Willem \\ Iskandar Pasar V-Kotak Pos No. 1589-Medan 20221, Indonesia. Tel. 62-8-13-8800-3000. E-mail: \\ jubliana_professeur@yahoo.co.id
}

Received: September 23, 2015 Accepted: November 19, 2015 Online Published: November 23, 2015

doi:10.5539/ass.v11n28p127

URL: http://dx.doi.org/10.5539/ass.v11n28p127

\begin{abstract}
Learning a foreign language is not just focused on learning the language grammatically, but also pragmatically that is spoken in accordance with the proper context. Mistakes in particular speech act speech act can have an impact on the problem of refusing to face up to conflict. This paper wants to see how the strategy of rejecting speech acts committed by Indonesian students who study French. Strategies analyzed by the selection vocabulary, effectiveness of sentences, sentence structure and politeness. Respondents are 30 students majoring in French at the University of Medan were selected based on purposive sampling technique. Data were collected using Discourse Completion Test (DCT). The results show that in the choice of vocabulary, many respondents use the verb is not appropriate to express rejection. Respondents were also frequent repetition of words in a sentence that makes the sentence to be long and rambling. In refusing, respondents are very polite, especially in the interaction between faculty and students. However, politeness is only indicated with concomitant use of words such as madame (madame), monsieur (sir) and excuse the expression (z) -moi (pardon me), je suis désolé (e) (I regret). Whereas for the polite form sentences in French can be used with conditionel mode, and other strategies such as the use of the phrase impersonnel, neutral pronoun use on, or the passive sentence. These strategies do not look at the answers of the respondents.
\end{abstract}

Keywords: pragmatics, speech acts, refusing

\section{Introduction}

Pragmatic and socio-cultural knowledge are two important things that cannot be ignored in language learning. Barriers in pragmatic and socio-cultural fields can cause problems in verbal interaction. These obstacles are much more difficult when compared to the mastery of the language itself. Mistakes happen, for example, when learners do not use the appropriate speech acts in the context of the interaction. It is on the one hand can lead to difficulties in the realization and interpretation of speech acts and on the other hand can interfere with interpersonal relationships of addressees.

To be able to establish a good relationship at the time of the verbal interaction, on the one hand addressees should use words that are good for keeping your face and avoid the other side acts that threaten the face. In fact, there is a communicative situation; in these situations face-threatening acts cannot be avoided, especially in speech acts rejected. In rejecting the speech acts, needed a way to find the right strategy to refine, limit the consequences threatening or disturbing.

Although the speech act rejecting a speech act that is universal, strategies refused certainly not identical between the speeches act one language to another language because of different socio-cultural. It is not possible misunderstandings can occur between native speakers with learners who are not native speakers in the same language, as it cannot convey the same message to communicate. Misunderstandings like this certainly can hinder social relationships that exist between native speakers and non-native speakers are.

The same thing can happen between foreign language learners who have a background of different first languages such as French students at the State University of Medan. During the lecture, students are not only equipped with knowledge of French language is grammatical, lexical but also knowledge of French culture itself. Armed with this knowledge, students are expected to be able to communicate in French by taking into account 
sociocultural aspects.

Assessment speech acts reject Indonesian students in French certainly will be very interesting and important because it enables the study examines the key points that the public and the realization of rejection in French. In-depth knowledge will be grammar, vocabulary and culture makes it possible to avoid conflict in the French-language interaction.

Based on the description described above, the authors are interested to know how the strategy of speech acts rejected by the Indonesian addressees in French. The strategy will be seen from four things: the selection of vocabulary, effectiveness of sentences, sentence structure and politeness.

\section{Studies Theory}

A speech acts not only have a way to deliver its speech. A speech can be expressed by a number of different statements that will certainly have an impact on the meaning of the statement. The strategy can be divided into speech act, speech act directly that statement directly, openly to exactly fit the addressees to be conveyed during the speech and indirect speech acts that speech acts done indirectly because of the existence of other measures.

\subsection{Speech Acts Refuse and Politeness}

Rejection is a response or a negative response is given to answer a request, invitation, and bids. (Kartomiharjo, 1993 , p. 147) denial strategy used in each language of course varies from one country to another. Not all languages or cultures reject the same way. As a result, cross-cultural communication, misunderstandings sometimes arise between native speakers with non-native speakers who use the same language but cannot convey the same message in communication (Yamagashira, 2001, p. 260).

In denial, how does one convey the word 'no' according to some people is more important than the answer itself (Al-Kahtani, 2005, p. 3). Therefore, it takes special skills to deliver and receive a rejection. Speakers should know when and how to understand the proper form and its functions are strongly influenced by the values contained in each social group.

Honglin (2007, p. 67) defines a speech act utterances spoken refused to form a reject action. In other words, rejection is a speech act that denies addressees to enter into the proposed action by opponents said Chen (1995, p. 12) basically addressees firmly against you for not doing an act that is refusing to do something. This action must be done to be careful because it can threaten the listener's face, or the opponents said.

This has encouraged the importance of civility in maintaining harmony in the interaction between the addressees and hearer. In this case the Leech (in Oka, 1993, pp. 206-207) establish the principles of cooperation in communication called maxims. The principle of civility or politesse principle as a benchmark for this study has 6 maxim, namely:

\section{a) Maxim of Policy}

The basic idea of the wisdom in the maxim of politeness principle is that the participants should adhere to the principle of substitutions to always reduce the benefit of him and others in the profit maximizing activity speak. Tells people who hold and carry out the maxim of wisdom will be said to be polite. (Wijana, 1996) says that the longer the person's speech, the greater the person's desire to be polite to his interlocutor. Similarly, the speech is expressed indirectly usually more polite than the speech expressed directly.

\section{b) Maxim of Mercy}

By Maxim generosity or maxim of generosity, the participants' substitutions are expected to respect others. Respect for others will happen if people can reduce the benefits for themselves and maximize the benefits for others.

\section{c) Maxim of Award}

In the award maxims explained that a person would be considered common courtesy when in speaking always try to give the award to the other party. With this maxim, it is expected that the participants of substitutions are not mutually mock, revile each other, or mutually demeaning others. Participants said that often mock the other said participants in the said activity will speak as a person who is not polite. Mocking said, because the action is an action does not respect others.

\section{d) Maxim of Simplicity (Humility)}

In the maxim of simplicity or maxims of humility, said participants are expected to be humble by reducing praise of him. People will say arrogant and supercilious careful if in activities speak always praise and favor himself. 


\section{e) Maxim of Agreement / Suitability}

In this maxim is expected that participants said could foster mutual agreement on the suitability or speak activity. If there is agreement or match between speaker and hearer themselves in activities speak, each of them can be said to be polite.

\section{f) Maxim of Sympathy}

This maxim is expressed with assertive and expressive speech. In sympathy maxims, it is expected that the participants said can maximize sympathy between one party with another party. If opponents said get success or happiness, speakers shall give congratulations. When opponents said received distress, or calamity speakers worth mourning, or express condolences as a sign of sympathy. Antipathy against one of the participants said no action would be considered polite.

In fact, not all communication transactions can meet these principles; because often a speaker (of necessity) should be violated or even ignore these principles. In such situations, the speaker was inevitably faced with a difficult choice. In the case of refusing, for example, speakers, on the one hand, are required to adhere to the principle of communication harmony, but on the other hand he had to break the rules earlier. Brown \& Levinson (1987) refer to such situations with Face-Threatening Acts (FTAs) situations. It happened because the speaker would not want to infringe or even make partners lose face he said. To reduce the level of 'offense faces' is this wisdom (read: politeness) speaks very necessary.

According to Brown \& Levinson, politeness shown by a speaker will be highly dependent on a few things: 1) how strong the level of power or influence that can be given by speakers to the partners he said (relative power), 2) how far social distance that exists between he said speakers and partners (social distance), and 3) how severe levels must carry out the wishes or requests hearer (ranking of imposition).

\subsection{Limitation of Pragmatics}

Leech (1983) also state that a pragmatic assessment be selected into 2 parts: pragma-linguistic and socio-pragmatics.

In general, pragmatic divided into two pragma-linguistic and socio-pragmatics. Pragma-linguistics is the study of general conditions of use of language communication. Pragma-linguistic pragmatics can be applied to study the purpose of which leads to the linguistic objectives, which we consider the resources provided by a specially formed for the express illocutionary language-specific illocutionary. Pragma-linguistic has a closed relation with grammar while socio-pragmatics is the study of the local conditions or local conditions more specific about the use of language. More specifically in the local community is seen that the co-operative principle or principles of cooperation and politeness principle take place by changing the culture of different or various language communities, in social situations and social classes are different, and so on. In other words, socio-pragmatics is a sociological pragmatics boundary. So it is clear how closely the socio-pragmatic sociology (Tarin, 1986, p. 25). Pragma-linguistic studies that were examined in this study include assessment of the realization of the French language student speech acts in terms of choice of vocabulary, sentence structure and effectiveness of the sentence.

\section{a) The Selection of the Vocabulary (diction)}

Diction is the ability of people utilizes the vocabulary in communication activities. Diction is strongly influenced by the richness of one's vocabulary. According Keraf (1999, p. 3) issue of diction or choice of words is much broader than the issue of establishing or stringing words in speaking, oral or written. The precision of word choice question the ability of a word chosen to generate ideas just in the imagination of the reader or listener like what is thought by the writer or the reader.

\section{b) Effective Sentences}

The sentence is said to be effective if it is able to make the delivery and receipt of messages takes place perfectly. Effectiveness is determined by compliance with rules, the idea of unity, coherence, clarity emphasis, diversity, frugality, the parallels and the logic reasoning.

\subsection{Learning a Speech Act of "Refusing" in French}

Speech acts of refusing from some French language teaching methods books. These examples are important as additional reference material to see how the strategy of speech acts of refusing in French language by French language learners.

Acte de langage de refus (speech acts of refusing in French), Cicurel (1991, p. 23) 
1. Non, je ne veux pas. C'est possible

2. Malheuresement, je ne suis pas libre mardi.

3. Non, je n'ai pas envie de la voir.

4. Je regrette, mais le magasin est fermé.

5. C'est dommage, je ne peux pas.

6. Je vais réfléchir.

7. Pas maintenant, je suis occupé.

8. Ça jamais!

9. Non, je n'irai pas chercher ton manteau.

10. Le président ne peut vous recevoir, je suis désolée.

11. Je refuse de répondre à cette question.

12. Tu rigoles!

13. Ce n'est pas possible dans l'immédiat, mais une autre fois peut-être.

14. Pas question!

15. Vous croyez que je n'ai que ça à faire!

16. Écoutez, vous n'y pensez pas!

17. Samedi? Franchement, je préfère venir un autre jour.

18. Non c'est non!

19. Pas ici, je t'en prie.

20. Tu as assez de vêtements, ça suffit.

Au secours!

... pas maintenant! Je suis occupé!

- J'irais bien au cinéma, ç ate dit?

- Ce soir?

- Ce soir, oui. Ça ne te dit pas?

- Je ne sais pas. Pour voir quoi?

- Ce que tu veux. J'ai le programme.

- Je ne sais pas. Il est tard, non?

- Mais non. Viens, je t'invite.

- Non, je suis fatigué. Je préfère rentrer.

- D'accord, je te ramène?

- Non merci, je vais prendre le bus.

Acte de langage de refus (Speech acts of "Refusing" in French), Martins (2003, pp. 14-16)

\section{Refuser un rendez- vous}

- Je regrette, ce n'est pas possible.

- Je regrette, mais je ne suis pas libre.

- C'est très gentil à vous mais j'ai déjà quelque chose.

- Ça serait avec plaisir mais...

- Cela aurait été avec plaisir mais ... (RECH)

- Désolé (e), je ne pourrai pas venir.

- Dommage mais je ne peux pas ce soir.

- Merci mais je ne peux vraiment pas. 
- Samedi, ça ne m'arrange pas.

- Je préfère un autre jour.

\section{Refuser de rendre service}

- Désolé mais je ne peux pas.

- Je regrette.

- Je ne peux pas vous aider.

- Je ne peux pas t'aider

- Ça m'emmerde. ( TRÈS FAM)

\section{Refuser une offerte de service}

- Ce n'est pas la peine, merci

- Merci c'est très gentil/aimable, mais ça va aller.

- C'est très gentil à vous, mais je trouverai une solution.

- C'est sympa de ta part mais je vais m'arranger.

- Merci, mais je vais me débrouiller.

\section{Refuser une permission}

- (C'est) non!

- C'est impossible.

- Je suis désolé (e) mais ce n'est pas possible.

- Je regrette mais les bureau sont fermés.

- Vous ne pouvez pas consulter ce document.

- Ça me dérange.

This study used a qualitative approach. Qualitative approach used as a framework approach this study with the aim to obtain a clearer description of the data collected from respondents. This approach is used to derive how the strategy refusal speech acts committed by Indonesian students by using French. Based on the frequency of use of speech acts rejection strategy, this research will get a general picture of the pattern or the strategy that is used to perform a speech act of rejection in French. Of the general pattern of these strategies, this study will describe and analyze the causes that appear in speech acts performed by the refusal of the French language learners.

Respondents in this study were 30 students majoring in French language of the State University of Medan. Determination of the respondents using purposive sampling technique in which these techniques include those selected on the basis of certain criteria that made researchers based on objective research. Purposive sampling technique was chosen for the study that prefers the depth of data than for the purpose of representation that can be generalized. The main issue in purposive technique is to determine the criteria, which criteria should support research purposes (Kriyantono, 2007, p. 115).

From these explanations, the subject of this study is the sixth semester student majoring in French, Faculty of Language and Art, State University of Medan. In addition, Students majoring in French which is the subject of research is already passing the DELF B1 level. By having the DELF B1 certificate, the students are considered able to follow a conversation in standard language, are long enough, it can give an opinion or ask for opinions from interlocuteur. May attempt to communicate in situations, which are offered on a trip in the area where the language is used. Can tell an event, travel and ideals, depicting hope or a goal and briefly displays reasons or explain a plan or idea.

Data collection techniques used is a question sheet in the form of DCT (Discourse Completion Test). In the data collection, the question sheet 16 DCT describes such situations call (invitation), requests, offers and suggestions. These sixteen situations were formed in a conversation format, and students were asked to play a role in each situation and respond as if they are in the actual situation. These sixteen situations were also divided into four groups based on the distance of respondents; between lecturer and student, between students level, between the junior and senior and between senior and junior.

The speech act strategies that will be analyzed in this study are based on: (1) vocabulary; (2) effectiveness, (3) 
structure, (4) politeness.

Table 1. Speech acts strategies of "refusing"

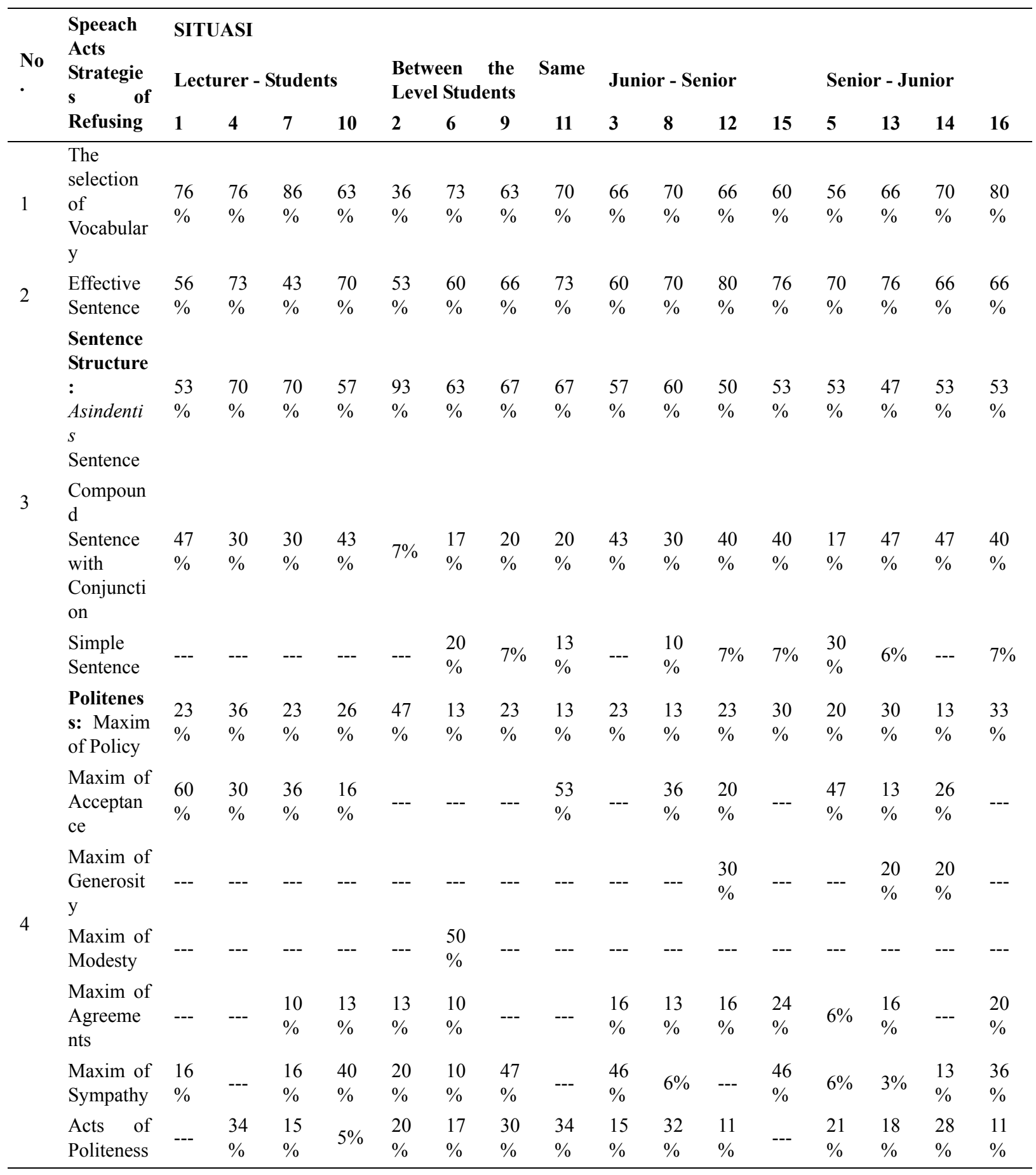

\section{Results and Discussion}

\subsection{The Selection of Vocabulary}

\section{a) Between lecturers and students}

Based on the data, on average $75 \%$ of respondents choosing the right vocabulary in performing speech acts rejected. Respondents answer according to the context, such as.

"Excusezmoi, enseigner mieux j'aime, j'aime ecrire, mais je n'aime Ecrivain pas être" 
(Forgive me, I prefer to teach, I love to write, but I do not like to be a writer).

However, the selection vocabulary errors most often done by the respondent is in the choice of verb. for example the use of pardonnez-moi (pardon me) who should have been more precise if respondents use the verb Excusez-moi.

"Pardonnez-moi, je ne jamais d'être un rêve Ecrivain". (not exactly)

"Excusez-moi, je ne jamais d'être un rêve Ecrivain". (right)

(Forgive me, I never dreamed of becoming a writer)

\section{b) Between Students in the same level}

Based on the table, it can be seen that the average respondent is able to form an effective sentence. However, these percentages indicate also found several errors. Just as in the situation between faculty and students, the respondent also still make mistakes choice of words on each apologized verb pardonner that the elections are supposed to use an excuse verb.

Moreover, the ambiguity with verbs emprunter (borrow) and préter (lend) are also common in the sentence. Respondents should use verbs emprunter, but using verbs préter that ultimately has an impact on changing the meaning of a sentence.

"Excusez-moi, je ne pas Peux t'emprunter de l'argent". (Not exactly)

(Excuse me, ma'am, I cannot borrow your money.)

"Excusez-moi madame, je ne pas te Peux prêter de l'argent". (Right)

(Excuse me, ma'am, I cannot lend you money.)

Other election errors vocabulary of nouns contained in the election, such as the designation mon ami (friend) that is unusual in French speech, while in the context of Indonesian communication is often found as "kak, bang or $d i k$ " to call a brother or female.

"Pardonne-moi, mon ami, Quelqu'un a Prete de l'argent, maintenant je N'Ai pas encore de l'argent, alors je ne pas Peux emprunter pour toi." (Improper).

(Forgive me, friend, someone to lend money, now I do not have any money, so I cannot borrow money for you)

Furthermore, the error also occurs in the selection of words between plusieurs (some for a slightly larger amount) and un peu (slightly). Supposedly, sentence followed by article INDEFINI un peu, but instead followed the INDEFINI plusieur article.

"Je ne pas Peux, the j'avais plusieurs d'argents, je te donnerais combine t'en besoin pour. (Improper)

"Je ne pas Peux, the j'avais beaucoup d'argent, je te combine donnerais en tu as besoin"(right)

(I cannot, if I have a lot of money, I will give how much do you want to)

Respondents also uses everyday words in French that are not standard in the sentence utterances such as adjectives Fauche (poor) should use the verb manquer de.

"Désolée maintenant je suis fauchée parceque acheteé j'ai beaucoup des livres"

Désolée maintenant je manque d'argent parceque acheteé j'ai beaucoup de livres.

(Unfortunately, now I do not have any money because I have bought a lot of books)

Respondents also use conjunctions improper reasons which respondents use parceque conjunctions (because) when it should puisque (because). In French, conjunctions parceque used to answer questions pourqoui (why). Puisque is used at the beginning of the sentence because the addressees and hearer know the issues discussed in the sentence.

"Désolée, parcequ'il ya une activité importante que je dois suivre dans mon organization." (Improper)

Désolée, puisqu'il ya une activité importante que je dois suivre dans mon organization". (Right)

(Unfortunately, because there is an important activity that should I follow in the organization)

"Je vous remercie madame, je ne pas Peux recevoir votre demande pour ce samedi " (improper)

"Je vous remercie madame, je ne pas accepter Peux votre demande pour ce samedi" (right)

(I am grateful to my mother; I cannot accept your invitation for this Saturday). 
Errors verbs election is also done by other respondents include: verb abbandonner $\rightarrow$ quitter; garder $\rightarrow$ soigner; étudier $\rightarrow$ suivre; finir $\rightarrow$ résoudre.

\section{c) Between Junior and Senior}

Based on the table can be seen that most of the respondents have been using the right vocabulary.

Some errors are most often done the same as in previous studies, namely on any apologize contained in Sentence Speech Acts Students are in the selection of verbs pardonner that should excuser, the ambiguity with verbs emprunter (borrow) and préter (lend) and misuse of conjunctions parceque that should use puisque

Other errors vocabulary election is a direct translation of the Indonesian contained on the use of the phrase, like the expression avoir une promesse (having promise) that should avoir un rendez-vous.

"J'ai une promesse avec un ami, excuse-moi, je ne pas aller Peux manger avec vous". (not exactly)

"J'ai un rendez-vous avec un ami, excuse-moi, je ne pas aller Peux manger avec vous". (right)

(I have promised with friend, forgive me, I cannot eat with you)

The term "bang, sis and bro" speech commonly used in Indonesian, but the term is not found in French culture, the respondents wanted to show the politeness using the word frère (the brother) were not in accordance with the French cultural context.

"Désolé frère, j'ai peur avec avec le professeur, il est souvent en colère dans la classe". (Improper)

"Je suis mon frère désolé, il n'est pas là, mon ami Prete ce livre". (Right)

(I am disappointed with my brother, his book did not exist, my friend borrows it)

In the French language to state the second person singular is used the word $t u$ (you) and vous (you, ye). Tu is used to peers, those who lower social status and to people who are very familiar as to the parents (father and mother) and another family. Vous used between strangers, which is a higher social status and is addressed to a second person plural.

"Je vous de votre idée remercie, je suis plus en travaillant adulte". (Not exactly)

(I say thank you for your advice, I am more mature while working.)

\section{d) Between senior and junior}

The answers given by the respondents mostly have been using vocabulary appropriate to the context. Errors most often done the same as in the previous study, namely in any apologize contained in KTTM namely in the selection pardonner verb that should excuser.

Another error is in the use of the verb. For example the use of verbs occuperer (overburden) on the situation 1e (a) is less precise, should the respondents use the verb déranger (disturbing / burdensome).

"Malheuresement, j'ai peur que je vous occuperer, je Peux étudier avec mes amis." (not exactly)

Malheuresement, j'ai peur de vous déranger, je Peux étudier avec mes amis. (right)

(With regret, I am afraid to bother you, I learned with my friends)

Mistakes use other verbs, i.e. the use of verbs repeter that should be reviser and verb recevoir, which should be accepted.

"C'est intéressant, mais je dois repeter toutes les Leçons pendant ce temps alors là, je ne pas aller avec vous Peux". (not exactly)

"C'est intéressant, mais je dois réviser toutes les Leçons pendant ce temps alors là, je ne pas aller avec vous Peux". (right)

(It is interesting, but I have to repeat all the subjects at the time, so I cannot go with you)

"C'est bon ça, je dois travailler en ce moment là, je ne pas Peux recevoir ton invitation". (not exactly)

"C'est bon ça, je dois travailler en ce moment là, je ne pas accepter ton Peux invitation". (right)

(Nice, I have to work at that time, I cannot accept the invitation) 


\subsection{Effective Sentences}

\section{a) Between lecturers and students}

In four of the existing situation, on average, $60 \%$ of respondents use an effective sentence when rejection in French.

"Je vous remercie madame, mais je dois faire mon projet, Peux je ne demande pas votre réaliser ".

(I am grateful to my mother, but I have to do my job, I cannot carry out your request).

Things that cause ineffectiveness sentence made by the respondents, among other things contained in laying pronouns. In French, the pronoun is placed after the subject or when using a two-verb sentence, the pronoun is placed between the two verbs.

"Merci madame, mais je ne vous aider Peux pas ce jour là". (ineffective)

Merci madame, mais je ne vous aider Peux pas ce jour là. (effective)

(Thanks mom, but I could not help her that day.)

Ineffectiveness sentence can also be caused due to an error laying adverbs in sentences. The adverb is usually placed after the verb. Examples of errors found in:

"Merci madame, ma famille Invite moi a passer les vacances aller à la campagne ensemble". (ineffective)

"Merci madame, ma famille à aller passer m'a Invite ensemble les vacances à la champagne". (effective)

(Thanks mom, I invited my family on vacation to the kampong)

Another aspect that makes the sentence becomes effective is the repetition of the same word in one sentence. For example sentences contained in:

"Non, je ne pas la classe suplémentaire Nette pendant les vacances, parce que je travaille pendant les vacances. Alors je ne pas Peux". (ineffective)

"Non, je ne pas la classe suplémentaire Nette, parce que je travaille pendant les vacances. Alors je ne pas Peux". (effective)

(No, I do not follow extra classes during the holidays because I was working during the holidays. So I cannot)

Other errors contained in the verb tense discrepancies usage. It is found in:

"Merci beaucoup monsieur, à votre invitation, monsieur, mais je ne pas Peux après la classe, je dois aller à l'Hôpital pour rendre visite à grande ma mère qui était malade". (ineffective).

(Thank you for the invitation pack, sir, but I cannot after class, I had to go to the hospital for my grandmother visited him being sick)

Other findings obtained in a data sentence speech that complex sentences are very long and rambling because in one sentence is very common sentence that exceeds two propositions.

\section{b) Between the Students in the Same Level}

Overall more than $50 \%$ of respondents were able to make effective rejection sentence. However, it remains found sentences are not effective. Things that lead to the ineffectiveness of the sentence, among others, the same as in the previous group are the same repetition of words, adverbial laying error, improper use of prepositions in a sentence. In addition we found several errors in the formation of negative sentences especially with objects that use partitive article.

Saving words can also be done to streamline the sentence. Sentences can be ineffective if after an adjective "désolé" is an appended comma and followed clause. It can be shortened by the use of adjective followed by the preposition de and added infinitive, two examples below is negative infinity.

"Désolé, mais je ne pas suivre Peux avec vous, je dois preparer mon Exposé pour demain". (ineffective)

"Désolé de ne pas aller avec vous, je dois preparer mon Exposé pour demain". (effective)

(Too bad cannot go with you, I have to prepare my presentation for tomorrow)

\section{c) Between Junior and Senior}

More than $60 \%$ of respondents were able to make an effective sentence in French. However, still found some errors. Things that cause ineffectiveness sentence among other things contained in the repetition of nouns, saving words can also be done to create sentences, became effective sentence. 
"J'utilise livres pour ces de mon references Chercher de Memoire, alors je ne pas te donner Peux ces livres." (Ineffective)

J'utilise pour ces Chercher des livres de mon references memoire Peux alors je ne pas te donner les. (effective).

A sentence that does not effectively use the clause in conjunction relatively que modified using prepositions and verbs followed the basic course.

"Je suis désolé, samedi j'ai beaucoup de devoirs de campus, il faut donner au professeur." (Ineffective)

"Je suis désolé, samedi j'ai beaucoup de devoirs du campus à donner au professeur." (Effective)

(I am so sorry, my Saturday a lot of homework on campus to be submitted to the lecturer)

Subsequently found some speech that is still wrong in using preposition.

In French pronouns placed after the subject or when using a two-verb sentence, the pronoun is placed between the two verbs.

"Merci de votre conseil, travailler encourage moi de travailler plus sérieusement." (Ineffective)

"Merci de votre conseil, travailler m'encourage d'étudier plus sérieusement". (effective)

(Thank you for your advice, work gave me a passion for learning more serious)

The ineffectiveness of the sentence in the above example is not only in laying pronouns but also the repetition of the same words. To be effective, you should replace a verb with another verb, but did not change the meaning.

\section{d) Between Senior and Junior}

Based on the results of the analysis can be seen that more than $60 \%$ of respondents using the effective sentence in the speech act rejecting between seniors and juniors are still the same as the situation in the previous situation, i.e. the repetition of nouns in the speech, saving words, laying pronouns.

\subsection{Sentence Structure}

Based on the table of the 16 existing situation can be seen that most respondents refuse to use complex sentences asindetis i.e. compound sentence has no conjunctions to bind propositions contained in the sentence, such as: Situation 6e (d):

" Je N'Ai pas envie de quitter cette organization, elle est importante pour moi".

(I did not want to leave this organization, it is very important to me).

In addition, respondents also use compound sentences that have a conjunction. In general, the conjunctions used are conjunctions resistance mais (but), alors (so) and conjunctions of cause and effect, parce que (due to):

"Je veux bien mais, ma vie est difficile tellement Peux ne pas que je te prêter de l'argen".

(I wanted to but life is very difficult, so I have not been able to also lend you money.)

"C'est très désolé mon amie, je suis malade encore, alors je dois beaucoup reposer me?"

(Unfortunate once friends, I was sick, so I had to rest a lot)

"Désolée, maintenant je suis fauchée parce que j'ai beaucoup de livres acheté".

(Unfortunately, now I'm not having the money because I have bought a lot of books.)

The findings obtained in a data sentence speech that complex sentences are very long and rambling because in one sentence is very common sentence that exceeds two propositions as an example in:

"Je suis trés désolé, il ya une activité familial, ce soir il ya une petite fête à la maison".

(I am very disappointed, there is a family event, and tonight there was a small party at home)

\subsection{Politeness}

Based on data from respondents, the majority of respondents indicated modesty in speech acts rejected. The level of politeness also studied based on politeness maxims of Leech, where respondents mostly use the maxim of wisdom and acceptance in performing speech acts rejected. Maxim of Policy is marked with an apology for not being able to realize the demand hearer and provide the reasons for rejection in ways that can benefit and not threaten the opponent's face said.

"Excusez-moi, je ne pas Peux, j'ai beaucoup de travail à faire."

(I'm sorry, I cannot, and there is a lot of work to do. 
Meanwhile, maxims receipt acknowledgments characterized by good demand and receive the hearer, before giving the refusal to give a face-saving excuse hearer.

"Je vous remerci madame, mais je dois faire mon projet, Peux je ne demande pas votre realiser."

(I say thank you, but I have to finish my work, I cannot realize your request)

The sentence begins gratitude because believed to jobs offered lecturers, and give reasons in denial. The sentence is very polite, but politeness according maxims only seen in gratitude, the title and content of rejection just as in Indonesian.

In French, the sentence can be formed more polite by changing the mode of verbs into conditionnel forms such as:

Je vous remercie madame, mais je faire mon projet devrais, pourrais je ne demande pas votre realiser.

(I say thank you ma'am, but I have to finish my project, I could not realize the mother's request)

Likewise with the sentence that describes the maxim of politeness sympathy:

Je suis désolé madame, je ne pas travailler Peux ce jour là, ma mère est venue de la campagne, je dois l'accompagner.

(I was disappointed $b u$, I could not work that day, my mother came from the village, I had to accompany him)

Based on the speech sentence by maxims that have been mentioned above, the respondents are not sensitive to the use of substitute process that emphasizes the use of conditional, impersonal sentence, on the use of pronouns and passive forms in expressing politeness in French to avoid the threat advance. All the verbs pouvoir, devoir, vouloir, avoir, aller être and to express politeness should be translated in the form of conditional, but not found in Sentence Speech Acts Speech Acts Students Reject although lasted between faculty and students.

\section{Conclusion}

After analyzing the sixteenth situation shared between faculty and students, the students level, juniors and seniors, as well as seniors and juniors, based on the selection of vocabulary, sentence effective, sentence structure and politeness, it can be seen how the students realize the speech acts rejection request or offer opponents said. In the words of speech found improper use of verbs. The respondents could not differentiate the use of verbs such as pardonner verba- and excuser, emprunter and préter, finir and resoudre, garder and soigner. Likewise with other verbs, verbs used to translate from Indonesian into French.

The ineffectiveness of the sentence contained in the improper placement of pronouns. The placement follows the pattern of Indonesian, while in French pronouns placed after the subject or when there are two verbs in a sentence, then placed between the two verbs. Likewise with the laying of the adverb, always placed at the end of a sentence, it should be placed after the verb and between verbs if the sentence has two verbs. Furthermore, the repetition of words is in a sentence to make a sentence into a protracted and very long. The other thing is the use of the article or the article before nouns profession, often found in the phrase that refers sentences in Indonesian. Verb tense becomes very difficult because in the mother tongue of students do not know when the verb, but to distinguish between the words, used words such aspects as now, will, later, have, already, etc. Another common mistake is the use of prepositions, the formation of a negative sentence with an infinitive verb, use subjunctive mode, and ignores the savings of sentences, etc.

Sentence speech consists of two parts: asindetis compound sentences without conjunctions and compound sentences with conjunctions. The first sentence types tend to be very long consisting of two or three propositions when compared with the speech acts the French in rejecting the form of a single sentence only (French language teaching methods). Similarly, the sentence of the second kind consists of two and three propositions. Conjunctions most dominant use is conjunction parce que (because) and mais (but). The sentence was very monotonous because it uses the same verbs and the same strategy and the same conjunctions similarly, while stating the same thing can be used conjunctions of different but the same grammar and meaning. The use of the phrase asindetis is more dominant, in every situation and a group of speakers.

In realizing speech refused, respondents were very polite. Politeness was shown by using maxims of politeness that is the maxim of policy, acceptance, sympathy and compatibility. The four maxims have become the dominant use in a sentence speech of students, especially maxims wisdom. Of the four groups, the level of politeness highest is between students and professors, Based on the analysis, strategy rejected as refuse in Indonesian, meaning politeness lies in the expression such as sorry, unfortunately, thanks and designations, monsieur (father), madame (mother). Meanwhile, to express politeness in French not only lies in the inclusion of 
elements as mentioned in the previous sentence, but it can also be combined with the process of substitution is in the mode of verbs, forms of passive sentences, use impressive sentence, and the use of neutral on the subject.

\section{References}

Austin, J. L. (1975). How To Do things With Words. New York: Oxford University Press. http://dx.doi.org/ 10.1093/acprof:oso/9780198245537.001.0001

Brown, P. D. S. C. L. (1987). Politeness: Some Universals in Language Usage. New York: Cambridge University Press.

Chen, H. J. (1995). Pragmatic Judgment on Refusals: Its Reliability and Consistency. Paper Presented at the Annual Meeting of the American Council on the Teaching of Foreign Language, 20th, Anaheim, CA, November 1995, (Eric Document No ED391381).

Francine, C. (1996). La construction interactive des discours de la classe de langue. Paris Hachette.

Honglin, L. (2007). A Comparative Study of Refusal Speech Acts in Chinese and American English. Canadian Social Science, 32, 569-582.

Kartomihardjo, S. (1988). Bahasa Cermin Kehidupan Masyarakat. Jakarta: Dikbud.

Keraf, G. (1999). Diksi dan gaya bahasa. Jakarta: PT. GRAMEDIA

Kriyantono, R. (2010). Teknik Praktis Riset Komunikasi: Disrertai Contoh Praktis Riset Media, Public Relations, Advertising, Komunikasi Organisasi, Komunikasi Pemasaran. Jakarta: Kencana Prenada Media Group.

Leech, G. (1993). Prinsi-prinsip Pragmatik (Diterjemahkan oleh M.D.D. Oka dari The Principles of Pragmatics). Jakarta: UI Press.

Penelope, B., \& Stephen, C. L. (1987). Politeness: Some Universals in Language Usage. New York: Cambridge University Press.

Tarigan, H. G. (1986). Pengajaran Pragmatik. Bandung: Angkasa.

Wijana, I. D. P. (1996). Dasar-dasar pragmatik. Yogyakarta: Andi offset.

Wijana, I. D. P. D. M. R. (2010). Sosiolinguistik: Kajian Teori dan Analisis. Yogyakarta: Pustaka Pelajar.

Yule, G. (1998). Pragmatics. Oxford: Oxford University Press.

\section{Copyrights}

Copyright for this article is retained by the author(s), with first publication rights granted to the journal.

This is an open-access article distributed under the terms and conditions of the Creative Commons Attribution license (http://creativecommons.org/licenses/by/3.0/). 